\title{
The Impact of Digital Technologies and Digitalization on Labour Law: the Case of Slovenia
}

\author{
MitJa STEFANCIC \& EliZABETA ZIRNSTEIN
}

\begin{abstract}
Building on research focusing on the impact of digital technologies on the labour market, this paper provides an interpretation of major findings by reference to labour law in Slovenia. It is argued that the existing labour law in Slovenia does a reasonable job in dealing with the changes we are witnessing in digital economy. However, the problem is in the implementation of workers « rights in practice. The workers are not taking action to enforce their legal rights as much as one could expect. In addition to this, employers do not put enough attention to the challenges that digitalisation brings in the field of health at work and in the field of workers" skills. Therefore, the Slovene government should embark upon a system of reforms to improve the promptness of courts in labour disputes. It should also appoint more labour inspectors. At the same time, employers should adopt practical solutions regarding the organisation of working process with aim to diminish the negative impacts of digitalisation on health at work. Furthermore, the employers should put more attention to the development of workers « skills, especially those which, according to theory, will be crucial in the future.
\end{abstract}

Keywords: - digital technology $\bullet$ technological progress $・$ Slovene labour law • employment relations • working conditions • social security $\bullet$

CORRESPONDENCE ADDRESS: Mitja Stefancic, PhD, Independent Researcher, Instituto EURICSE (affiliated), Via Torre Verde, 7, 38122 Trento TN, Italy, e-mail: mitja.s@ hotmail.it. Elizabeta Zirnstein, PhD, Associated Professor, University of Primorska, Faculty of management, Cankarjeva 5, 6000 Koper, Slovenia, e-mail: elizabeta.zirnstein@fmkp.si.

UDC: $65.011 .8+349.2(497.4)$ 
\begin{tabular}{l|l}
120 & $\begin{array}{l}\text { LEXONOMICA } \\
\text { M. Stefancic \& E. Zirnstein: The Impact of Digital Technologies and Digitalization on Labour } \\
\text { Law: the Case of Slovenia }\end{array}$
\end{tabular}

\section{$1 \quad$ Introduction}

The focus of this paper is on the impact of the digital economy on contemporary work and labour conditions. This topic is addressed primarily from a legal point of view although insights from other fields are considered as well. When reading the paper, the reader should bear in mind the following questions: Do the current and future technological as well as economic changes demand a shift in the labour law framework, starting from an improved definition of basic concepts such as »employment« and »workers« rights«? How should different actors including the employers, the employees (workers) and states adapt not only to this changing reality but also to new standards and conditions set by the markets?

There is little doubt that digitalisation has a profound impact not only on the lives of citizens but also upon the ways in which both work and progress are conceived of (Brynjolfsson and Mcafee, 2014). Authors such as Beck (2000) have argued that we no longer live in a society based on certainties. To the contrary, daily we have to face uncertainties and risks in our everyday lives. ${ }^{1}$ If each national economy in the past managed to secure its way to a standardized production matched by a standardized type of consumption, things changed substantially - particularly over the last few decades. It is the so-called »risk regimes « that, according to Beck, we are bound to live in. These new regimes »firmly rule out any eventual recovery of the old certainties of standardize work, standard life histories, an old-style welfare state, national economic and labour policies « (Beck 2000: 70). As demonstrated by Aubert-Tarby et al. (2018: 1), the development of digital technologies is among the biggest disruptions that has happened in decades.

Digitalisation (that is, the massive use of digital technologies in the workplace and in everyday life) should not necessarily be viewed in a negative way, as it provides many significant benefits. For instance, according to Katz and Koutroumpis (2013), there is a strong correlation between the level of digitalisation, economic growth and social welfare. Some studies also show a positive impact of digitalisation on job creation (Sabbagh et al., 2013; Koutrompis, 2009), though there are important differences between industries in this regard. Some industries experience a net destruction of jobs, while others manage to create new jobs. Activities that are most frequently subject to automation include workers in logistics and transportation occupations (Frey and Osborne, 2017: 268), as well as those in accounting and backoffice transaction processing. It is important to note, however, that even when some tasks are being automatized, employment in those occupations may not decline significantly as workers may perform new kinds of tasks.

The impact of technological change on employment goes beyond the question of job creation or destruction. In fact, it relates to the issue of job quality, i.e. job security and wages (Aubert-Tarby et al., 2018: 39). According to Sweet and Meiksins (2008), with the rise of a global economy, standards for the employees and members of the workforce have worsened constantly both in the US and in other countries,

\footnotetext{
${ }^{1}$ This argument applies particularly to the job market.
} 
partly due to the lack of responses that should have been provided both in the political sphere and by trade unions (and as a result of the liberalization of markets that often neglects issues such as the rights of employees and quality of employment relations). Furthermore, Freeman and Perez (1988) argue that technological change leads to the emergence of a new techno-economic paradigm, in which both the quality and quantity of labour are directly affected.

In this paper, we investigate the impact of digitalization on different aspects of labour in Slovenia - a country that over the past few decades has experienced substantial social and economic changes together with some unexpected problems in the economic and political system (Prijon, 2012; Guardiancich, 2016). We focus on this topic primarily from a legal point of view and by assuming that digitalization is a trend that will continue to be central to policies in the years to come. Although there are some studies that try to investigate the labour law issues of digitalization, they mainly focus on some specific problems without adequately addressing the larger framework in which this topic should be contextualized. The present paper tries to fill the above mentioned gap by evaluating the main challenges that digitalization represents for labour law issues in Slovenia from a wider perspective.

The paper is structured as follows. Chapter 2 summarizes the recent findings on the impact of digitalization on the job market in general and on working conditions in particular. Chapter 3 provides an interpretation of these findings by reference to the labour law framework in Slovenia. Subsequently, chapter 4 sets some preliminary concluding remarks.

\section{The technological revolution in the $21^{\text {st }}$ century and the development of work}

Vast literature exists on the relationship between technology, modes of production and employment, dating back to at least Marx. The possibility that technology will replace workers was also discussed by many economists, including J.M. Keynes (1930: 3), who coined the concept of »technological unemployment « to define the kind of employment originating from technological advancement. In recent years, Autor et al. (2003) made a major theoretical contribution to the understanding of the relation between digital technology and employment. Their research shows that a number of jobs are likely to disappear due to the implementation of new technologies which, in turn, are going to determine the ways in which products and services are being conceived, produced and marketed. For instance, this is due to the fact that since the 1990s, labour input of non-routine tasks (which include low skill manual tasks and knowledge intensive non-manual tasks) is growing, whereas at the same time the labour input of routine manual tasks is declining. Indeed, over the past decades, computers have been used as substitutes for human labour to perform a variety of tasks (Bresnahan, 1999), mostly routine manual tasks. Recently, Frey and Osborne (2013) also showed that non-routine tasks can be carried out by the socalled »computer capital« (e.g. autonomous driving cars, but several other examples 
$122 \begin{aligned} & \text { LEXONOMICA } \\ & \text { M. Stefancic \& E. Zirnstein: The Impact of Digital Technologies and Digitalization on Labour } \\ & \text { Law: the Case of Slovenia }\end{aligned}$

can be observed today, for example a robot waitress in $\mathrm{Japan}^{2}$ and the Google A.I. Assistant $^{3}$ ).

In addition to the automation and digitalization of tasks that were in the past performed by people (human labour force), Autor and Dorn (2013) discuss structural changes in the labour market, with workers reallocating from middle-income manufacturing to low-income service occupations. This originates from the fact that jobs in service occupations are less susceptible to computerization in comparison to jobs in the manufacturing sector, as they require a higher degree of flexibility and physical adaptability (Goos and Manning, 2007). Furthermore, Goos and Manning (2007) showed that non-routine tasks are mainly located in the top level of wage distribution; this was confirmed by Maurin and Thesmar (2004) who investigated this issue in France. This helps to explain the employment growth in occupations that involve a great amount of cognitive tasks.

Arguably, in the coming years a large number of jobs could be performed by computerized systems (eg. those based on algorithms). Although the abovementioned studies report of a negative impact of technological change on employment, other studies find a rather positive impact of digitalisation on job creation. For example, Luksha et al. (2015) studied the effects of technology on Russian jobs until 2030and concluded that new jobs will be created by digital technologies. In their study, they also emphasize the need for future employees to develop cross-professional skills in order to remain competitive on the market. Studies run by the CEDEFOP (2015) predict that new occupations will rise especially in architecture, engineering, computer and mathematics. Some scholars argue that the technological revolution will stimulate human employment in the service and manufacturing sectors (Moretti, 2010; Goos et al., 2015).

In addition to this, some scholars find no evidence supporting the notion that standard occupations might disappear entirely; by contrast, their research shows that only some tasks are bound to be replaced by technology and technological devices (McKinsey, 2015; Fernandez-Macias, Bisello, 2016). They argue that, ultimately, technology will not be able to replace all the tasks involved in a particular occupation. This is the case, they argue, because automation changes only the task content of occupationsbut does not eliminate occupations entirely (or does so very rarely).

Employment conditions in the digital economy is an issue that can be studied also from the qualitative point of view (and not only by means of quantitative analytical tools). Working conditions and settings are changing rapidly, as more and more jobs and tasks are moving from the offline to the online economy, defined as the "platform economy« (ILO, 2018a). Although studies report that the level of employment in digital platforms is still relatively low (Farrell and Greig, 2016; European Parliament, 2017; Pesole et al., 2018), nevertheless it is expected to

\footnotetext{
${ }^{2}$ See https://www.youtube.com/watch?v=3OgFZovYS9U

${ }^{3}$ See https://www.youtube.com/watch?v=D5VN56jQMWM
} 
increase in the future, especially as developing countries have already adopted strategies that encourage employees to engage in digital labour (Graham et al, 2017). What is most relevant from the perspective of the authors of this paper is the quality of jobs being generated by the platform economy. Activities and/or services that are performed online are in theory encompassed within the term »crowd-work «. The main characteristic of crowd-work is that it is easily conducted anywhere as long as a reliable internet connection is provided. Crowd workers may choose the place, the time shifts and the typology of work. Additionally, the tasks to be perform may be set in advance (Felstiner, 2011; Barnes et al., 2015), meaning that work is by definition very flexible. On the other hand, however, this form of work arrangement translates not only into longer working hours but also a blurring of divides between life at work and private life. In addition to this, analyses (ILO 2018b; Eurofund 2015) provide evidence on the lack of transparency (clarity) with regards to the employment status of crowd-workers, low earnings, and a lack of social protection. Some of these issues are addressed in the following section.

\section{The impact of technological progress on the concept of work and on labour conditions}

In the past decades, the labour conditions in the so called advanced economies shifted from more or less stable and predictable working environments to constantly changing environments. What is the effect of technological change on work and on labour conditions? The aim of this section is to address this question from a number of different perspectives. The first one refers to the quality of jobs created. Are newly created jobs likely to result in regular permanent employment contracts or is it more likely that new jobs will be of the casual contractual nature? The difference is not insubstantial since regular employment contracts provide protections not only against risks such as illness, disability and temporary unemployment, but also conditions for retirement from the job. The second concern refers to working conditions. What is the impact of digitalisation on health and well-being at the workplace? Does digitalisation impact the definition of working and non-working hours? The third (and the last) concern relates to the concept of employment itself: what is the exact definition of »worker« provided by law and how accurately can one distinguish between categories of workers and non-workers, employed and unemployed, etc.?

From the point of view of labour law, the fact that we are at the same time facing job destruction and job creation (the net effect is still unpredictable) is as important as the question of the quality of jobs created in comparison to jobs being destroyed.

While there is little doubt that, overall, technological change has been highly beneficial to our societies, it is also obvious that the introduction of a new technology does not make everybody better off. For instance, most digital platforms classify the workers as independent contractors (ILO, 2018b, 4). This means that the workers are not being afforded any labour protections, such as illness, disability and unemployment, and they are not included in retirement schemes. In addition to this, workers categorized as independent contractors are solely responsible for the 
\begin{tabular}{l|l}
124 & $\begin{array}{l}\text { LEXONOMICA } \\
\text { M. Stefancic \& E. Zirnstein: The Impact of Digital Technologies and Digitalization on Labour } \\
\text { Law: the Case of Slovenia }\end{array}$
\end{tabular}

payment of social security contributions. Although some of these workers are in fact legitimately self-employed, as Rogers (2016) points out, in many instances they may be misclassified so that those hiring them can avoid employment law obligations.

Furthermore, there is a clear popularization of the freelance jobs (White, 2012). Even though some freelancers work as platform workers, the majority of them still operate in a real work setting, albeit on the basis of civil law contracts. The problem with freelancers is the same as mentioned in the previous paragraph: they are not granted adequate labour law protection (as of general standards). This is the case even though some people may enjoy the freedom afforded by freelancing and thus prefer it to any kind of standard employment arrangement. In addition to this, freelancers typically do not contribute to social security and they have no access to health insurance or pension schemes. There are regional variations, however, with workers in Western Europe, for example, enjoying better contracts (standards) than those working in Eastern Europe, Asia, Africa and Latin America (ILO, 2018: 4).

The employment status of workers has a significant impact also on the average earnings of employees. Some scholars show that crowd-workers receive on average low pay (Bergvall-Kareborn, Howcroft, 2014). Only in cases of jobs that require very specific competencies or knowledge, linked to the digital technology, are the earnings higher (Acemoglu, Autor, 2010).

The employment status also has a significant impact upon workers « skills development. A good job is one that provides access to training, encourages career development and provides new opportunities. The implementation of new technologies encourages employers to ensure appropriate training programmes for their employees, while workers that are in informal employment (freelancers, platform workers etc.) are often excluded from such a possibility. Such workers must rely upon their own initiative to build on their skills and to develop competencies required by the job market. If they do not, their position, when compared to that of regularly employed workers, may worsen significantly in time; they may be at risk of long-term unemployment. The gap between employed workers and other workers is increasing. At the same time, employers have to find new ways to attract workers with the right skills and competencies. Employers place a high premium on workers having problem-solving skills, adaptability and creativity (Autor, 2015). In any case, there is evidence demonstrating that career adaptability is becoming increasingly important in the digital economy (Guang et al., 2014).

Ensuring good working conditions is an important task in labour law, as they contribute not only to the physical and psychological well-being of workers but also help to insure e a proper balance of working vs. personal hours. How are digital technologies affecting the chances of workers to find a proper balance between the time spent at work and leisure time?

Research shows that new jobs are less life-hazardous (Aubert-Tarby et al., 2018: 2). However, the concerns that digitalisation raise in the arena of labour law are not as 
much related to physical safety issues such as injuries and ergonometric conditions, as they are to psychosocial ones: an increasing risk of social isolation, the nonspecificity of tasks and flexible working hours with subsequent worsening of life standards of the individual person (ILO, 2018: 20).

Workers have unprecedented freedom to perform their tasks from any location at any time, and sometimes do not even have a boss to check their performance. This translates into large autonomy and an easier reconciliation of working and nonworking life. Nevertheless, one of the unforeseen outcomes resulting from digitalisation is that the boundaries between working time and non-working time have become increasingly blurred. Employers demand full availability from their employees at any time of the day, including during week-ends. Employees are expected to check their e-mails regularly even when they are on vacation or are at home because they are ill. Excessive hours of work have become a fact. In addition to this, the fact that platform workers do not have a boss who oversees them does not mean that their work is not subject to evaluation or control. Those workers are subject to "algorithmic management« (Lee et al., 2015), which means that their work is assessed by an algorithm.

\section{Is there a need for new and different solutions in the Slovene labour law?}

In this section we try to evaluate the impact of digitalisation with particular reference to labour law in Slovenia. The case for selecting this country is straightforward: being a relatively stable country, it is nevertheless subject to important changes. Furthermore, while wealth was in the past well-distributed among citizens of Slovenia, social inequalities and disparities have increased substantially during the last ten years as shown by data for the Gini ${ }^{4}$ (Filipovič Hrast and Ignjatovič (2013). In the following paragraphs, we draw the attention to the main challenges that digitalization may represent for the Slovene labour law. These are: the quality of new jobs created, the quality of working conditions for those new jobs, and the concept of employment itself.

As mentioned above, scholarly literature addresses the impacts of digitalisation on Slovene labour law only partially. Tičar (2016), Kresal (2017) and Franca (2018) draw attention only to labour law issues arising from crowd-work. Senčur Peček (2017) focuses on the relation between digitalization, working time and health at work issues. In comparison to the above mentioned authors, only Končar (2016) provides a broader analysis of challenges that digitalization represents for the labour law, such as diminishing boundaries between work and private life, new types of risk for health at work, working hours, and notions of labour relationship etc.

\footnotetext{
${ }^{4}$ The Gini index measures the extent to which the distribution of income (or, in some cases, consumption expenditure) among individuals or households within an economy deviates from a perfectly equal distribution (ILO 2002: 135, 137).
} 


\subsection{The quality of jobs created}

Having an employment contract is essential for Slovene workers as such a contract is a condition precedent for Slovene collective labour and social security laws to apply. As explained in the previous section, one of the effects of digitalisation and technological progress is a decline of regular permanent employment contracts, which are slowly being replaced by non-standard, non-permanent and casual civil law contracts. Research shows that this is the case also in Slovenia (Širok et al., 2018; Senčur Peček, 2017). Workers in this type of »employment« are usually offered the possibility to sign a civil law contract. In the case of platform work, they are not even given an opportunity to sign a contract, and instead they simply accept the terms and conditions of the platform as the provider of work. Under these circumstances, their legal position depends on whether they fall within the scope of article 4 of the Labour Relations Act. ${ }^{5}$ Such workers (platform workers, freelance workers, crowd workers) are considered to be in an employment relationship if the work is performed in exchange for wages, during a certain time and in the subordination to the employer. In other words, the same labour law protection applies for all categories of workers. The problem in practice, however, rests in the enforcement of that protection (more is argued under the concept of employment, see below). In addition to this, it happens in some cases that even when crowd workers and freelancers are classified as regularly employed, the obstacle to accessing employment security is the changing nature of their employment conditions/contracts.

\subsection{Working conditions in Slovenia}

The second important issue regarding the digital work environment involves the working conditions that pertain to the worker. Digital technologies can negatively affect the balance between the time spent at work and at leisure. In Slovenia, the debate on work-life balance, especially on reconciliation of work and family life, is relatively new and has been promoted by projects and initiatives of the Ministry of Labour, Family and Social Affairs (the certificate »Family Friendly Enterprise« is a good example of such initiatives). The legislation has also focused on providing an even distribution of work/care at home between men and women (see Parental Protection and Family Benefits Act). ${ }^{6}$

With regards to working time and time off work, the Employment Relationships Act defines full working time as a time between 36 and 40 hours per week (article 136). ${ }^{7}$ The 30-minute break is included in the working time (article 154). An employer must enable a rest of 12 hours between two working days (i.e. daily rest 12 hours in a 24-hour period, article 155) and a weekly rest of at least 24 hours once per week (along with daily rest, article 156). An employer must organize the work process in accordance with prescribed weekly and monthly restrictions. Overtime work is limited to a maximum 8 working hours per week, 20 working hours per month and

\footnotetext{
${ }^{5}$ Official Journal of the Republic of Slovenia, No 21/13, 78/13, 47/15, 33/16, 52/16 and 15/17.

${ }^{6}$ Official Journal of the Republic of Slovenia, No 26/14, 90/15, 75/17 and 14/18.

${ }^{7}$ Where there is a great risk of injury or harm to health, full working time may be under 36 hours a week.
} 
170 working hours per year (article 144$).{ }^{8}$ An employer is not permitted to ask certain protected employee categories (pregnant women, elderly workers, workers who operate in dangerous settings etc., article 146) to work overtime. In cases of an unequal distribution or temporary distribution of full working time, the latter may not be more than 56 hours per week, and this distribution cannot exceed a period of 6 months (article 148). A night worker «s working time over a period of four months cannot exceed more than eight hours per day (article 152).

All of the above-cited articles apply not only to workers in a regular employment relationship, but also to workers that work on a different legal basis (i.e. crowd workers, freelancers), assuming that the requirements from article 4 of the Employment Relationships Act are met (e.g. if they can be considered employees). However, the effect of those rules in practice is disputable, as restrictions of working time are often violated regardless of the legal basis of the »employment relationship«. Accordingly, the reality of the situation is that the life-work balance in Slovenia does not depend on the law, which if actually applied does adequately regulate working hours a. Unfortunately, however, the life-work balance depends on employers being aware of the importance of that balance and employees enforcing their rights. We are of the opinion that employees are constrained to enforce those rights in practice, mainly because of the fear of reprisals. Violation of the rules on working time is supervised by the employment inspectorate on the basis of appeals and announcements. However, the inadequate number of labour inspectors in Slovenia prohibits them from conducting the inspection procedure within a short time after they receive a notice of the violation; it normally takes more than one month (in the best case) for inspector to begin the inspection. This unreasonable delay, in turn, has a deterrent effect on the motivation of workers to start such procedures. Furthermore, we believe that the solution regarding life-work balance is not in the enforcement of the above mentioned rules on working hours, but in the restrictions on the quantity of work that a single worker has to perform. In the cases, when working hours are constantly exceeded on the company level, the employer should hire new workers or at least re-organise the working process with aim to reduce the workload per worker. Therefore, the solutions regarding the rules on working time lie in the enforcement of workers « rights and restrictions regarding the quantity of work per worker not in the changes of legislation.

\subsection{The concept of employment as defined by the Slovene labour law}

As described above and in the previous section, the problem inherent in platform and freelance work centres around the lack of adequate labour law protection and social protection for these classes of workers. Most platform and freelance workers in Slovenia (who are, in most cases, self-employed) have to agree to the terms and conditions of the contract, otherwise they are simply not hired. These individuals face a classic Hobson «s choice: take it or leave it. Increasingly, many choose to »take it« out of financial necessity, but in the process are then deprived of the social

\footnotetext{
${ }^{8}$ Exceptionally, upon the employee «s consent, this limit can be extended to 230 working hours per year for certain occupations such as healthcare; however, this should be agreed in the collective agreement that applies to the occupation or in the occupational collective agreement.
} 
\begin{tabular}{l|l}
128 & $\begin{array}{l}\text { LEXONOMICA } \\
\text { M. Stefancic \& E. Zirnstein: The Impact of Digital Technologies and Digitalization on Labour } \\
\text { Law: the Case of Slovenia }\end{array}$
\end{tabular}

net provided to the traditional full-time worker under Slovene law. Those terms often contain »independent-contractor clauses «, stipulating that the worker is not an employee and consequently s/he is not awarded protection and benefits that apply to regular employees. In the terms of labour law in Slovenia, those clauses are not decisive for the legal position of a worker. In Slovenia, the question of employment status is a question of fact (and not the question of law). ${ }^{9}$ The essential criteria to identify »employees« is regulated by article 4 of the Employment Relationships Act (as described in the previous section).

The Act defines employment relations as »relationships between the worker and the employer, whereby the worker integrates voluntarily in the employer «s organized working process, in which he in return for remuneration continuously carries out work in person according to the instructions and under the supervision of the employer « (Article 4 of the Act). Consequently, both a platform and a freelance worker is deemed to be in an employment relationship, if all of those elements exist (the worker must perform work in exchange of wages, personally, during a certain time, in the subordination to the employer). So, even if a platform or a freelance worker agrees to a contract with an independent-contractor clause, this does not mean that $\mathrm{s} / \mathrm{he}$ is not awarded any labour law protection. However, if the employer does not acknowledge the fact that there is an employment relationship established by law, the worker has to use legal remedies to ascertain his or her rights. In practice, the workers are reserved to inforce their rights by filing a lawsuit, a lengthy legal process that takes at least a year, and during the pendency of which they have no job and just basic social security coverage. In addition to this, the changing nature of their employment conditions and contracts often results in a conclusion that not all elements of employment relationship exist (article 4 of the Employment Relationships Act).

The last question in this section deals with the development of workers « skills. As described in the previous section, implementation of new technologies forces employers to ensure appropriate training programs for their employees. While in Slovenia this is perceived as something positive in the eyes of younger employees, the older ones are sometimes not so keen to change their competencies every five years. Especially, those employers who are soon to be retired often just want to be left in peace and lack the incentives to train younger workers, which after all comes at the expense of both money and energy. The challenge for Slovene employers is therefore the implementation of appropriate strategies to motivate also older workers for continuous development of new skills. An example of good practice is The Competence Centre »Steklar ${ }^{10}$ that was financed by the European social fund.

\footnotetext{
${ }^{9}$ The employment relationship exists in all cases when the elements from the article 4 of the Employment Relationship Act exist. Therefore, the real situation in practice is crucial, not the existence of a written employment contract.

${ }^{10}$ In Slovene: Kompetenčni center Steklar. The aim of the project was to build on competencies and skills of glassworkers included in the project and to stenghten their personal development.
} 
Digitalisation driven by technological innovation is bringing new challenges to the world of work. This is with no doubt also the case for Slovenia - a country that has undergone substantial social, political and economic changes during the last few decades. In Slovenia (as elsewhere) the proportion of the so-called flexible work relations is steadily increasing as a consequence of automation and computerization. Subsequently, different issues concerning employment and social protection are emerging. In this paper, we addressed some of these aspects from the point of view of the effects of digitalisation on the very nature of work as well as on labour conditions in general. We also tried to provide an evaluation of the most pressing issues with reference to labour law in Slovenia.

Labour law in Slovenia can be useful to both maintain and further develop a good level of working standards, yet it is not sufficient by itself. From a practical perspective, the quality of new jobs, working conditions and the legal definition of employment are altogether affected by the process of digitalization as well as other developments that are changing the ways in which the work in Slovenia is being organized and performed. This is matched by a rise of the so-called freelance jobs and non-standard forms of employment, with a lower level of labour protection. We argue that the problem is not as much in the labour legislation. The implementation of legal solutions is insufficient. A lot of challenges that arise from digitalisation can be solved in practice, using a reasonable approach.

Throughout this paper we argued that the existing labour law in Slovenia does a reasonable job in dealing with the changes we are witnessing in digital economy. But the formal laws can only do so much and have their limitations. Instead, the problem is in the implementation of workers « rights in practice. The implementation, not the legislation, is insufficient and not always adequate. The workers are not taking action to enforce their legal rights as much as one could expect. It can be suggested that this is mainly due to the fact that legal processes in this regards take too long. There is an old saying that »Justice delayed is justice denied « and that saying holds true under Slovene labour law. Therefore, the Slovene government and judicial system should start to improve the promptness of courts and appoint more labour inspectors. A solution in the long run could also be the application of a universal rights approach: namely, the development of a framework of minimum rights could be designed on an international level, for all workers, whatever their status.

In addition to the legal concerns, important implications may arise from extant studies that have been reviewed in this paper. For example, a lack of training has been cited as a major problem of workers in non-standard forms of employment. Also, anxiety and insecurity may result from unsecure employment status, leading to high levels of stress - often difficult to bear at the individual level. People might also experience a sense of poor prospects in terms of career opportunities. Finally, flexible working conditions can become very demanding and are thus difficult to 
handle in the long term. All these issues may ultimately lead to levels of productivity that are far from being optimal for firm owners/managers.

Lastly, the growth in non-standard forms of employment is providing a new challenge for trade unions who need to protect workers engaged in forms of employment other than the usual standard employment. As we did not include this view in our study, let us in the end suggest that the traditional industrial relations model based on collective bargaining cannot be applied to the self-employed, freelance workers and platform workers. They represent a special challenge for unions « policies and for strategies aimed to secure workers« representation. This is true also for Slovenia. If they will succeed in their effort to recruit members from all these different types and forms of employment, further developments will probably follow in the area of labour law (collective bargaining).

\section{References}

Acemoglu, D., Autor, D. (2010) Skills, Tasks and Technologies: Implications for Employment and Earnings, NBER Working Paper Series 16082 (Cambridge: National Bureau of Economic Research).

Aubert-Tarby, C., Escobar, O., Rayna, T. (2018) The impact of technological change on employment: The case of press digitization, Technological Forecasting \& Social Change 128 (3), pp. 36-45.

Autor, D., Levy, F., Murnane, R.J. (2003) The skill content of recent technological change: an empirical exploration. The Quaterly Journal of Economics 118 (4), pp. 12791333.

Barnes, S. A., Green, A., de Hoyos, M. (2015) Crowdsourcing and work: Individual factors and circumstances influencing employability, New Technology, Work and Employment 30 (1), pp. 16-31.

Beck, U. (2000) The Brave New World of Work (Cambridge: Polity Press).

Bergvall-Kareborn, B., Howcroft D. (2014) Amazon Mechanical Turk and the Commodification of Labour, New Technology, Work and Employment 29 (3) pp. $213-223$.

Brynjolfsson, E., McAfee, A. (2011) Race against the machine: how the digital revolution is accelerating innovation, driving productivity, and irreversibly transforming employment and the economy (Lexington: Digital Frontier Press).

Brynjolfsson, E., McAfee, A. (2014) The Second Machine Age. Work, Progress and Prosperity in a Time of Brillian Technologies (London: Norton).

David, B. (2017) Computer technology and probable job destructions in Japan: an evaluation, Journal of the Japanese and International Economise 43 (1), pp. 77-87.

Employment Relationships Act. Official Journal of Republic of Slovenia, no 21/13, 78/13, $47 / 15,33 / 16,52 / 16$ and $15 / 17$.

Eurofund (2015) New forms of employment (Luxembourg: Publications Office of the European Union).

European Centre for the Development of Vocational Training - CEDEFOP (2018) Skill shortages in Europe: Which occupations are in demand - and why. [http://www.cedefop.europa.eu/en/news-and-press/news/skill-shortages-europewhich-occupations-are-demand-and-why ] (visited: 26.11.2018).

Felstiner, A. (2011) Working the crowd: Employment and labour law in the crowdsourcing industry, Berkeley Journal of Employment and Labour Law 32 (1), pp. 143-204. 


\section{LEXONOMICA \\ M. Stefancic \& E. Zirnstein: The Impact of Digital Technologies and Digitalization on \\ Labour Law: the Case of Slovenia}

Filipovič Hrast, M., Ignjatovič, L. (2013) GINI Country Report: Growing Inequalities and their Impacts in Slovenia. [http://giniresearch.org/system/uploads/506/original/Slovenia.pdf?1372768022] (visited 11.12.2018).

Franca, V. (2018) Delovnopravno varstvo vokolju spletne platforme, X. posvet Pravo in ekonomija: Digitalno gospodarstvo, konferenčni zbornik, Maribor, 1. December 2018, pp, 31-51.

Freeman, C., Perez, C. (1988) Structural crisis of adjustment, business cycles and investment behaviour, Technical Change and Economic Theory (London: Pinter Publishers), pp. $38-66$.

Frey, C., Osborne, M. (2013) The Future of Employment: How Susceptible Are Jobs to Computerisation? Technological Forecasting and Social change 144 (1), pp. 254280.

Goos, M., Manning, A., Salomons, A. (2009). Job polarization in Europe, American Economic Review 99 (2), pp. 58 - 63.

Guardiancich, I. (2016) Slovenia: The End of a Success Story? When a Partial Reform Equilibrium Turns Bad, Europe Asia Studies 68 (2), pp. 205-231.

ILO (2002) Key Indicators of the Labour Market (KILM) (Geneva: International Labour Organisation).[https://www.ilo.org/wcmsp5/groups/public/---dgreports/--stat/documents/publication/wcms_498929.pdf] (visited 16.12.2018)

ILO (2018a) Job quality in the platform economy: Issue brief, prepared for the 2nd Meeting of the Global Commission on the Future of Work, 15-17 February 2018 [http://www.ilo.org/wcmsp5/groups/public/---dgreports/--cabinet/documents/publication/wcms_618167.pdf ] (visited: 26.11.2018)

ILO (2018b) The future of Work: A literature Review. Research Department Working Paper no 29. [https://www.ilo.org/wcmsp5/groups/public/---dgreports/--inst/documents/publication/wcms_625866.pdf] (visited 20.11.2018).

Katz, R.L., Koutroumpis, P. (2013) Measuring digitization: a growth and welfare multiplier, Technoinovation 33 (10-11), pp. 314-319.

Keynes, J.M. (1933) Economic possibilities for our grandchildren [http://www.econ.yale.edu/smith/econ116a/keynes1.pdf] (visited: 24.11.2018).

Končar, P. (2016) Digitalizacija - izzivi za delovno pravo, Delavci in delodajalci 16 (2-3), pp. 257-268.

Koutroumpis, P. (2009) The Economic Impact of Broadband on Growth: A Simultaneous Approach, Telecommunications Policy 33 (9), pp. 471-85.

Kresal, B. (2017) Delo v času »delitvene ekonomije«, »sodelovalnega gospodarstva« in »spletnih platform«, Podjetje in delo 19 (6/7), pp. 1161-1178.

Lee, S., McCann, D. (2011) Regulating for Decent Work: New Directions in Labour Market Regulation (Basingstoke, Geneva: , Palgrave Macmillan, ILO).

Parental Protection and Family Benefits Act. Official Journal of Republic of Slovenia, no 26/14, 90/15, 75/17 and 14/18.

Pesole, A., Urzi Brancati, C., Fernandez-Macias, E., Biagi, F., Gonzalez Vazquez, I. (2018) Platform workers in Europe: Evidence from the COLLEEM survey, Joint Research Centre (Luxembourg: Publications Office of the European Union).

Prijon, L. (2012) Successfulness of Slovenian Economic Transition? Slovak Journal of Political Sciences 12 (3), pp. 210-223.

Rogers, B. (2016) Employment rights in the platform economy: Getting back to basics, Harvard Law and Policy Review 10 (2), pp. 479-520.

Sabbagh, K., Friedrich, R., El-Darwiche, B., Singh, M., Koster, A. (2013) Digitization for economic growth and jobcreation: Regional and industry perspectives, The Global Information Technology Report 2013, pp. 35-42. 
$132 \begin{aligned} & \text { LEXONOMICA } \\ & \text { M. Stefancic \& E. Zirnstein: The Impact of Digital Technologies and Digitalization on Labour } \\ & \text { Law: the Case of Slovenia }\end{aligned}$

Senčur- Peček, D. 2017. Vpliv informacijske tehnologije na delovna razmerja. Podjetje in delo 19 (6/7), pp. $1178-1184$.

Sweet, S., Meiksins, P. (2008) Changing Contour of Work: Jobs and Opportunities in the New Economy (Thousand Oaks: Pine Forge Press).

Širok, K., Laporšek, S., Sedmak, S., Zirnstein, E. (2018) Novi avtonomni delavci v Sloveniji: Izzivi zaradi razširjanja novih atipičnih oblik dela, IB revija : za strokovna in metodološka vprašanja gospodarskega, prostorskega in socialnega razvoja Slovenije, 52 (1), pp. 5-17.

Tičar, L. (2016) Vpliv digitalizacije na pojav novih oblik dela, Delavci in delodajalci 16 (2-3), pp. 241-255.

White, A. (2012) The digital labour challenge: Work in the age of the new media, Working Paper No. 287 (Geneva: International Labour Office). 